\title{
敷地地盤の微振動調查に基づく 免震建物の微振動応答予測手法
}

\section{MICRO-VIBRATION PREDICTION METHOD IN A BASE ISOLATED BUILDING BASED ON MICRO- VIBRATION RECORDS IN CONSTRUCTION SITE}

\author{
深澤尚宏 — $* 1 \quad$ 北村春幸 $-* 2$ \\ 藤田隆史 一 $-* 3$ 浅野美次 一 $* 4$ \\ 安田正志 - $* 5$ 吉江慶祐 — 6 \\ キーワード : \\ 微振動, 免震建物, 応答予測, 基礎入力動, 減衰定数 \\ Keywords : \\ Micro-vibration, Base-isolated building, Response prediction method, \\ Foundation input motion, Damping factor
}

Takahiro FUKAZAWA - $* 1$
Takafumi FUJITA $-* 3$
Masashi YASUDA $-* 5$

Haruyuki KITAMURA - *2
Mitsugu ASANO $-* 4$
Keisuke YOSHIE $-* 6$

In recent years, the base isolated structure is adopted as the building of various uses, with the apparatus which should be prevented from micro-vibration. Base-isolated buildings are divided from ground. Accordingly it's said that base isolated buildings may be disadvantageous in term of micro-vibration and it's important to predict the characteristics of vibration easily in term of planning of buildings.

This paper describes a method of response analysis of micro-vibration in base-isolated buildings, adopting simple model which based on same value of planning and using it to simulate vibration responses.

\section{1.はじめに}

近年、1994 年ノースリッジ地震、1995 年兵庫県南部地震、1999 年台湾集集大地震など、都市部の建築物や産業施設に大きな被害を 与える大地震が頻繁に起きるとともに、様々な用途の建物に免震構 造が採用されるようになってきた。微振動を嫌う精密機器類を持つ 研究所や工場などにも、生産設備の地震被害を回避する目的で免震 構造が採用され始めている。

免震構造は地盤と縁を切った構造であるため、1) 地盤への逸散减 衰が期待できず、微振動レベルでは減衰の少ない構造であること、

2) 免震層による振動の增幅が考えられること、3）1）により内部振 動源に対して摇れやすくなることなど、微振動に不利な側面が考え られる。このため、一般建物と異なる免震建物特有の微振動特性を 把握しておくことは重要であると考える。また、建物内の微振動レ ベルが精密機器の要求する微振動レベルを満足できない場合、機器 免震などで除振を行う必要があり、建設計画時点において建物床面 の微振動レベルや微振動特性の概略の把握が必要となってくる。

そこで、筆者らは精密工場などに関与する振動として、振動加速 度レベルにして $50 \mathrm{~dB}$ 以下、振動数において $0.5 \mathrm{~Hz}$ から $30 \mathrm{~Hz}$ まで の微振動を対象として、種々の地盤、基礎、構造形式を持つ実在免 震建物の微振動調查を実施し、微振動の地盤から免震建物への伝達 特性、免震建物における微振動の応答性状について分析、評価を行 ってきた。122,33本報告は、これらの調查、研究で得られた成果をま とめ、計画中の免震建物の微振動レベルを把握することを目的に、 敷地地盤の微振動測定デー夕を基に、免震建物の床応答を予測する
手法を提示し、実建物の微振動調查に基づき、その応答予測手法の 妥当性を評価する。

\section{2. 免震建物の微振動予測手法と微振動測定}

本研究での微振動予測手法は、計画中の免震建物の微振動予測を 行うことを目標としている。計画時点で予測を行う場合、ある程度 の予測精度を確保した上で、出来るだけ簡便なモデルとすることが 望ましい。本研究では、簡便なモデルによる応答予測手法を提案し、

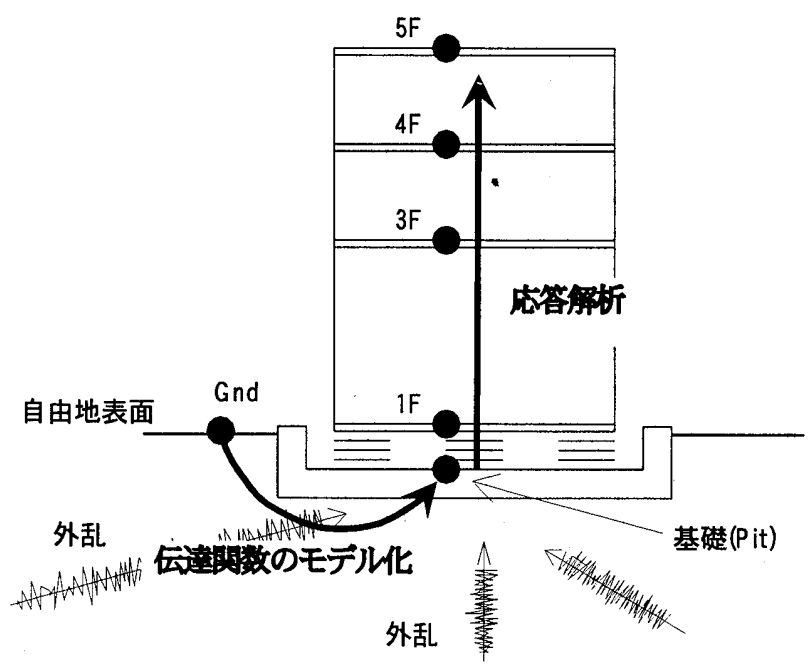

図 1 微振動予測概念図

\footnotetext{
*1 元東京理科大学大学院 (現静岡県庁)

(干278-8510 千葉県野田方山崎2641)

$* 2$ 東京理科大学 教授. 工博

*3 東京大学生産技術研究所 教授・工博

*4 日建設計東京本社 工博

*5 特許機器(侏) 工博

*6 日建設計東京本社
}

*1 Former, Graduate School of Tokyo University of Science

*2 Prof., Tokyo University of Science, Dr. Eng.

*3 Prof., Institute of Industrial Science, University of Tokyo, Dr. Eng.

*4 Nikken Sekkei Ltd., Dr. Eng.

*5 Tokkyokiki Corp., Dr. Eng.

*6 Nikken Sekkei Ltd. 


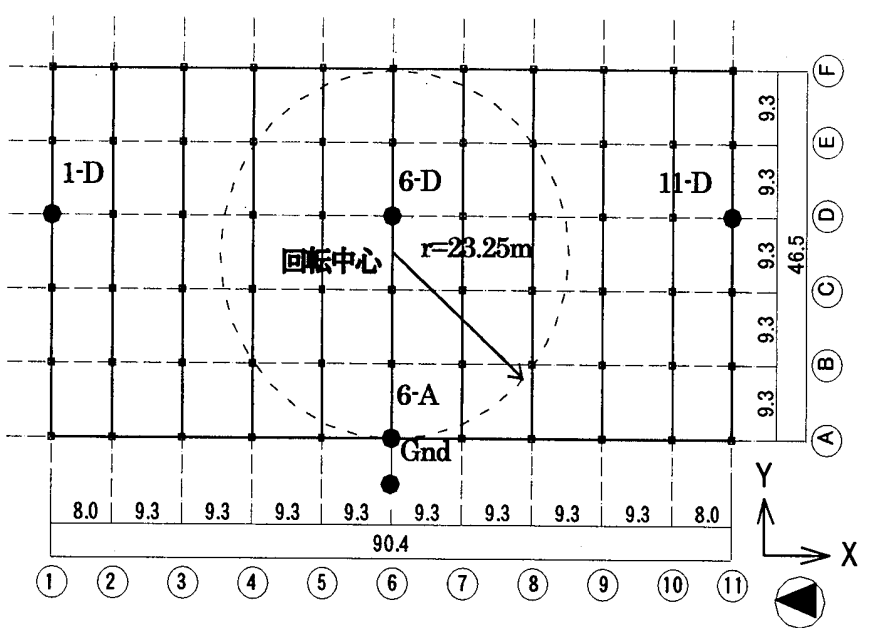

図2 建物平面図

表 1 地盤構成

\begin{tabular}{|c|c|c|c|c|c|}
\hline 土質 & \begin{tabular}{|c} 
梁度 \\
$(\mathrm{m})$
\end{tabular} & $\begin{array}{c}\text { 層厚 } \\
(\mathrm{m})\end{array}$ & 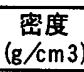 & $\begin{array}{c}V p \\
(m / s e c\end{array}$ & $\begin{array}{c}\text { Vs } \\
(\mathrm{m} / \mathrm{sec})\end{array}$ \\
\hline $\begin{array}{l}\text { ローム、䂺湿りの黒ボク } \\
\text { ローム }\end{array}$ & 2.5 & 2.5 & 1.44 & 480 & 140 \\
\hline 磁混りローム & 3.2 & 0.7 & 1.73 & 1000 & 400 \\
\hline 砂磷、磁湿り砂 & 4.7 & 1.5 & 1.84 & \multirow{2}{*}{1430} & 390 \\
\hline 砂碰 & 7 & 2.3 & 1.89 & & 670 \\
\hline 粘土混り砂碟 & 9 & 2 & 1.99 & \multirow{2}{*}{1630} & \multirow{2}{*}{680} \\
\hline 弦混りシルト䀦砂 & 10.4 & 1.4 & 1.91 & & \\
\hline
\end{tabular}

実建物の微振動測定值と予測值を比較検討することにより、その予 測精度を検討する。

自由地表面の微振動から免震建物内床面の微振動を予測する手法 として、(1)地盤から基礎への伝達 (2)基礎を入力とする免震建物の 応答予測に分ける。(図 1)

(1)では、地盤に対する基礎の幾何学的拘束効果を減衰フィルタと して扱う方法の検討、(2)では、簡便な解析モデルとして建物をスウ エイ・ロッキングモデルとしたときの予測值の精度を検討する。

なお、本報告では、建物の振動源は地盤の微振動のみとし、検討 に当たり水平動のみを対象としている。風力や建物内部の振動に対 する応答並びに上下動については別途考慮するものとした。

評価建物としてここでは: 静岡県磐田市にある精密作業工場を選 んだ。地上 5 階、塔屋 2 階、建築面積 4,710 $\mathrm{m}^{2}$ 、延べ面積 $14,615 \mathrm{~m}^{2}$ の免震建物である。基礎は独立フーチング基礎直接地業であり、上 部構造の X(長辺)方向は、内側に架構を組まず、外周部の RC 造而震 壁付きラーメン架構のみで水平力を負担する。Y(短辺)方向内側は $\mathrm{RC}$ ラーメン架構と外周部の $\mathrm{RC}$ 造耐震壁付きラーメン構造となっ ている。床スラブは、 RC プレキャスト板である。免震層は、天然 ゴム系積層ゴムに鉿ダンパーと鋼棒ダンパーを組み合わせ、1 階床 下に配置している。図 2,3 に測定建物の平面図、断面図を示す。表 1 に敷地の地盤構成を示す。基礎は、Vs=400m/s の磷混じりローム層 に直接支持されている。

本報告で比較検討に用いた実測波は、竣工直前の 2001 年 1 月 16 日 8：00〜18：00に行った微振動測定記録を採用した。天候は、弱 風・䍣天、建物内及び敷地内の外乱振動は、ほぼ無い状態であった。 波形 No.1 から No.4 が測定時間 600 秒、サンプリング時間 $128 \mathrm{~Hz}$ 、 波形 No.5,6 が測定時間 180 秒、サンプリング時間 $100 \mathrm{~Hz}$ で 5 また は6チャンネルを同時測定した。測定点一覧を表 2 に示す。なお、

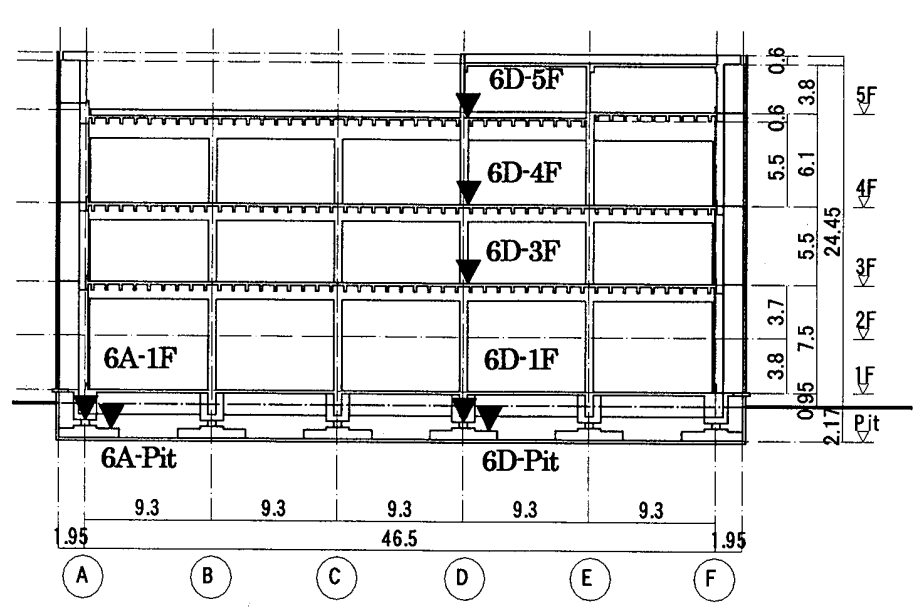

図 3 建物断面図 (6 通り)

表 2 測定点一覧

\begin{tabular}{|c|c|c|c|c|c|c|c|c|c|}
\hline 皮形 & 測定方唐 & \multicolumn{6}{|c|}{ 同時測定点 } & $T(\mathrm{sec})$ & $\Delta T(H z)$ \\
\hline 1 & $\bar{x}$ & GND & $6 A-P I T$ & $6 \mathrm{D}+\mathrm{PIT}$ & $6 \mathrm{~A}-1 \mathrm{~F}$ & $6 \mathrm{D}-1 \mathrm{~F}$ & & 600 & 128 \\
\hline 2 & $\bar{Y}$ & GND & 6A-PIT & 6D-PIT & $6 \mathrm{~A}-1 \mathrm{~F}$ & $6 \mathrm{D}-1 \mathrm{~F}$ & & 600 & 128 \\
\hline 3 & $\bar{x}$ & GND & $6 \mathrm{D}+\mathrm{PIT}$ & $6 \mathrm{D}-1 \mathrm{~F}$ & $6 D-3 F$ & $6 \mathrm{D}-4 \mathrm{~F}$ & $6 D-5 F$ & 600 & 128 \\
\hline 4 & $Y$ & GND & 6D-PIT & $6 \mathrm{D}-1 \mathrm{~F}$ & $6 \mathrm{D}-3 \mathrm{~F}$ & $6 D-4 F$ & $6 D-5 F$ & 600 & 128 \\
\hline 5 & $\bar{x}$ & 11D-PIT & $6 \mathrm{D}-1 \mathrm{~F}$ & $110-1 \mathrm{~F}$ & $11 D-3 F$ & $11 \mathrm{D}-4 \mathrm{~F}$ & $11 D-5 F$ & 180 & 100 \\
\hline 6 & $Y$ & 11D-PIT & $6 D-1 F$ & $11 \mathrm{D}-1 \mathrm{~F}$ & $11 D-3 F$ & $11 D-4 F$ & $11 D-5 F$ & 180 & 100 \\
\hline
\end{tabular}

$\mathrm{T}:$ データ長さ $\Delta \mathrm{T}$ :サンプリング間隔

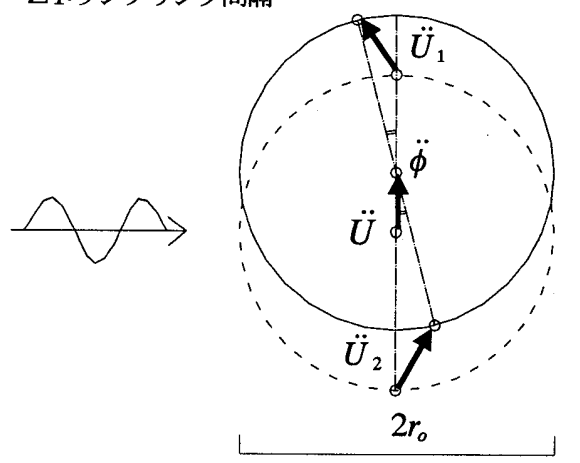

図 4 円形基礎での位相差による動き

Gnd は建物近傍の地表面、Pit $1 \mathrm{~F}$ は上下免震基礎面、 $3 \mathrm{~F} \cdot 4 \mathrm{~F} \cdot 5 \mathrm{~F}$ は各階柱際床面である。

\section{3. 地盤から基礎への伝達特性の評価}

地震時と同様に微振動においても、地表面上の振動がそのままそ の地点に建つ構造物への入力動にはならず、位相差により水平動で は高振動数側で伝達特性の落ち込みが起こる。また、通常の水平 2 成分の他、垂直軸に関する㨝れ成分も構造物に作用する。この為、 自由地表面からの応答予測を行う場合、地盤に対する基礎の幾何学 的拘束効果を考慮する必要がある。地震動に位相差を考慮したとき の、自由地表面と基礎の入力動との関係を表す周波数伝達関数が井 口 4)により求められており、本論ではそれを微振動に適用し基礎の 入力動の算出を試みる。

\section{（1）微振動記録に基づく水平動と㧖れ動の算出}

図 4 の様な理想的な円形の基礎の場合、基礎全体の水平動と㨝れ による基礎端部の加速度は、以下のように表せる。

$\begin{array}{ll}\ddot{U}=\left(\ddot{U}_{1}+\ddot{U}_{2}\right) / 2 & \text { 水平動 } \\ r_{o} \ddot{\phi}=\left(\ddot{U}_{1}-\ddot{U}_{2}\right) / 2 & \text { 挨れ動 }\end{array}$ 
この式を本物件の波形 No.1 の 6-D と 6-A に適用し、回転中心を $\mathrm{C}$ 通りと $\mathrm{D}$ 通りの中間と仮定すると以下のような式に変形し、基礎 全体の水平動・6-A での据れ動を求める。

$\ddot{U}=\left(23.25 \times \ddot{U}_{6-D}+4.65 \times \ddot{U}_{6-A}\right) / 27.9 \quad$ 水平動

$r \ddot{\phi}=23.25 \times\left(\ddot{U}_{6-D}-\ddot{U}_{6-A}\right) / 27.9 \quad$ 㨝れ動

ここで、 $\ddot{U}_{6-D} \cdot \ddot{U}_{6-A}$ は 6-D、6-A での加速度、 $r$ は回転中心から 端部までの距離である。

波形 No.1 の地盤・基礎での微振動波形と式(3)(4)より求めた基礎 部の水平動成分・㨝れ動成分の 40 秒から 50 秒までの時刻歴加速度 波形を図 5 に示す。

自由地表面上での加速度に比べて、基礎での加速度の大きさは約 1/10にまで減っており、微振動においても位相差による影響がある ことがわかる。水平動と㨝れ動を比較すると、基䃈端部での㨝れ動 が無視できないことがわかる。

(2) 入力損失フィルタ

ラブ波、SH 波の斜め入射による矩形基礎の自由地表面上での地 震動と基礎の運動との周波数伝達関数は、井口によって次式 4)で示 されている。

$\ddot{U}_{X i}=F_{H}(\omega) \ddot{U}_{X o}, \quad \ddot{U}_{Y i}=F_{H}(\omega) \ddot{U}_{Y o}$

$\ddot{\phi}_{i}=F_{\theta X}(\omega) \ddot{U}_{X o}+F_{\theta Y}(\omega) \ddot{U}_{Y o}$

$F_{H}(\omega)=\frac{\sin \left(\tilde{a}_{0} \cos \alpha\right)}{\tilde{a}_{0} \cos \alpha}$

$F_{\theta X}(\omega)=i \cdot\left(\frac{6 L x}{L x^{2}+L y^{2}}\right) \cdot\left\{\frac{\cos \left(\tilde{a}_{0} \cos \alpha\right)}{\tilde{a}_{0} \cos \alpha}-\frac{\sin \left(\tilde{a}_{0} \cos \alpha\right)}{\left(\tilde{a}_{0} \cos \alpha\right)^{2}}\right\}$

$\tilde{a}_{0}=\frac{\omega \cdot L x}{2 V s} \quad F_{H}(\omega), F_{\theta}(\omega)$ :水平、据え回転の伝達関数

$L x, L y$ :基礎幅 $\alpha$ :地表面から見た入射角 $V s$ : 地盤のせん断波速度

今、微振動における据れを誘起させる波は地表面を伝わってくる と仮定し入射角 $\alpha=0$ とすると、式(7),(8)は以下のように書き表され る。

$F_{H}(\omega)=\frac{\sin \tilde{a}_{0}}{\tilde{a}_{0}}$

$F_{\theta X}(\omega)=i \cdot\left(\frac{6 L x}{L x^{2}+L y^{2}}\right) \cdot\left\{\frac{\cos \tilde{a}_{0}}{\tilde{a}_{0}}-\frac{\sin \tilde{a}_{0}}{\tilde{a}_{0}^{2}}\right\}$

図 6 に、実測波を用いて式(3),(4)により分離した水平動成分、㨝れ 動成分と自由地表面上での実測波との伝達特性を細実線で、各方向 の諸元を式(9),(10)に代入して得られた並進動、㨝れ動の理論値を太 実線で示す。細実線で示す実測值の伝達特性は、それぞれのデー夕 を 8192 点に分割し 4096 点をオーバーラップさせながら各小サンプ ルを高速フーリ工変換(FFT)し、それを加算平均して求めた。せん断 波速度は、表層地盤の Vs=140m/s と建物基礎接地地盤の Vs=400m/s の值が考えられることから、両者について検討を行つた結果、建物 基礎接地地盤の Vs=400m/s を使用した方が、予測精度を確保するこ とができることより、Vs=400m/s とした。

水平動では、 $4 \mathrm{~Hz}$ を境に実測値の伝達特性が落ち込んでおり、理 論值の方が低い振動数で落ち込みが見られる。これは理論值が剛体 基礎として解かれているのに対し、実際には基礎の変形により拘束
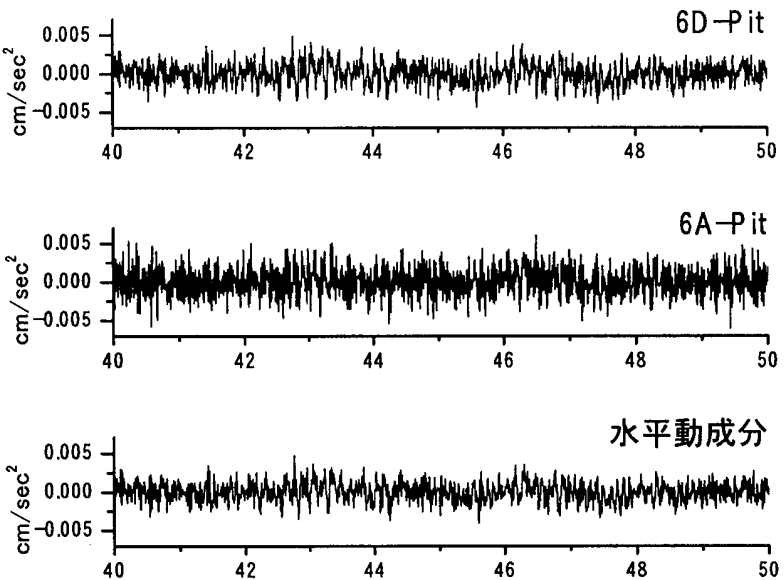

㨭れ動成分

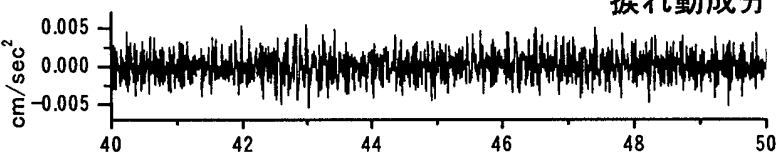

Gnd

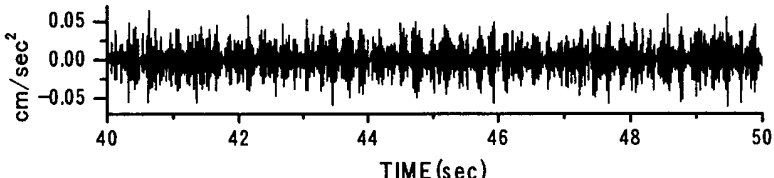

図 $5 \mathrm{Pit} \cdot \mathrm{Gnd}$ と算出された水平動・㨝れ動成分の加速度波形

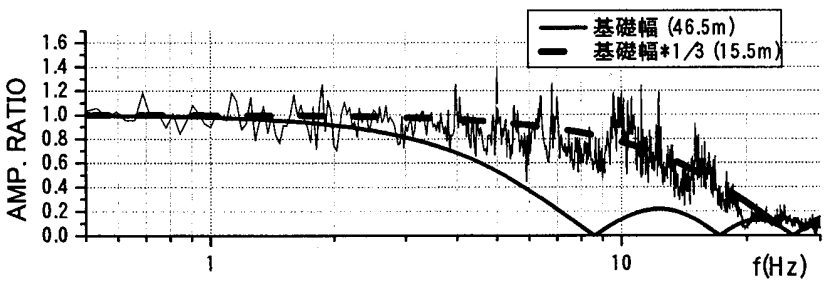

(a)水平動

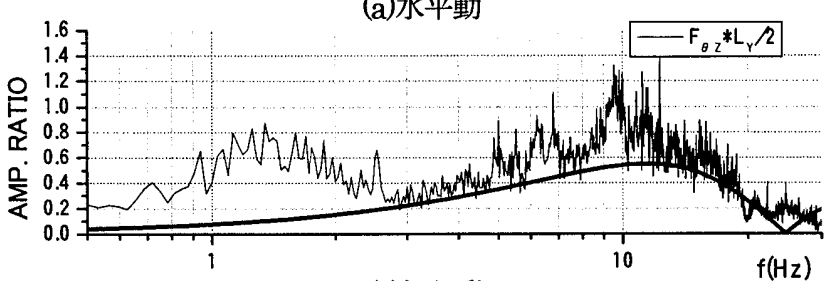

(b)据れ動

図 6 実測より求まる基礎と地表面の伝達と入力損失フィル夕

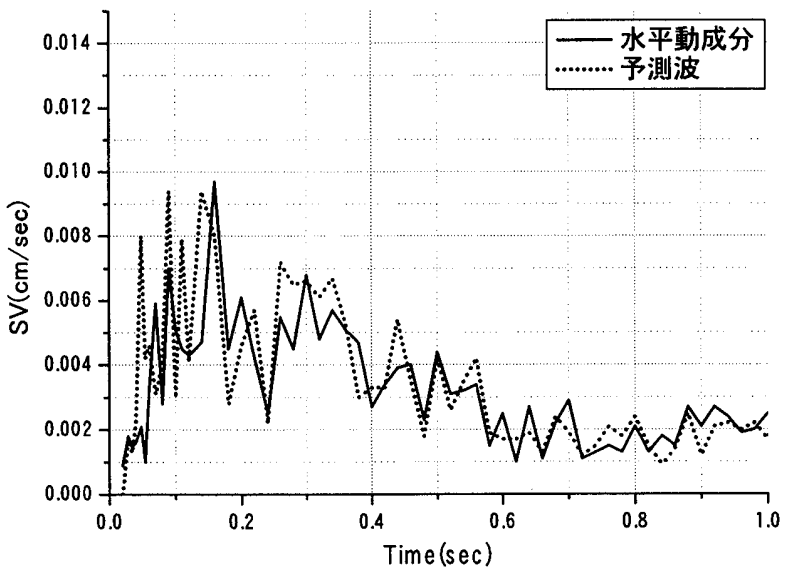

図 7 基礎入力動 (速度応答スペクトル) 
効果が低下するからである。実測值は理論值の基礎幅を $1 / 3$ 程度に した值とよく合った。伝達関数を求める際には、基礎柔性の効果を 考慮し基礎幅を低减させる必要があり、基礎柔性の程度により基礎 幅を低減する指標の作成が今後の課題である。据れ動では、水平動 ほど明確に特徴が見られないが、理論值とよく似た形状となってい る。

図 7 に実測波の水平動成分と、基礎幅を $1 / 3$ としたときの水平動 伝達関数を自由地表面上の実測波に掛け、逆FFTによって求めた予 測波の速度応答スペクトルを示す。実測波の水平動成分の概略を概 ね掴めることが分かる。

\section{4. 減衰定数}

免震建物の微振動応答における減衰定数をどの程度に設定すれば よいのかは、過去のデータがあまりないため地震応答解析における 慣例に頼ることが多い。そこで本章では、免震建物の微振動測定デ 一夕に基づき減衰推定を行う。

本研究では建物の減衰を推定するために入出力デー夕を用いる ARMAX モデル5)のによって減衰定数を同定した。測定を行った日は 無風であり、風の影響はごく微小である。

同定の対象とする範囲は、 $\mathrm{X} ・ \mathrm{Y}$ 方向とも $1.6 \mathrm{~Hz}$ 付近に見られる 各方向の 1 次と、 $5.5 \mathrm{~Hz}$ 付近に見られる 2 次を対象として行った。 なお、X方向の $2.2 \mathrm{~Hz}$ 付近に見られるピークは同年 2 月 10 日〜 4 月 13 日、9 月 10 日の測定では見られず、建物の振動特性に起因するも のではない内部振動によるものと考えられる為、このピークでの減衰は 今回の同定の対象から外した。同定は、デー夕長さ 300 秒を 1 セット とし、波形 No.3 から No.6 を用いて XY 方向各次 3 セットについて 行った。

ARMAX モデルでの推定では、シミュレーションデータの時間長 さを固定し、デー夕の間引きにより同定の際の時間刻み $\Delta \mathrm{T}$ を調節 する。この際、エイリアジングを防止するため、ナイキスト振動数 $\Delta \mathrm{f}_{\mathrm{N}}$ に対し、 $0.8 \Delta \mathrm{f}_{\mathrm{N}}$ をカットオフ振動数とするフィル夕により高振動 数成分を除去する。モデル次数は、スペクトルの形状を FFTによる 伝達と比較することにより 30 次に決定した。図 9 に波形 No.1(X 方 向)と波形 No.2(Y 方向)それぞれの 0 秒から 300 秒までの 6D-PIT と 6D-5F との ARMAX モデルによる推定結果を実線で、高速フーリエ 変換(FFT)による結果を点で示した。FFTによる推定は、300秒の入 出力デー夕を時間長さ 32 秒間で 50\%オーバーラップさせながら 18 セットのサンプルに分割して、それらのアンサンブル平均を推定値 とした。図9に推定された減衰定数と振動数を示す。

推定された減衰はX方向の 1 次で $1.7 \%$ から $2.1 \%$ 、2 次では $1.8 \%$ から $2.3 \%$ の減衰であった。 $\mathrm{Y}$ 方向の 1 次では $1.9 \%$ から $2.4 \%$ 、2 次

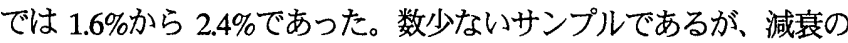
值は、2\%前後の値をとると思われる。これより免震建物の微振動解 析では、定值減衰 $2 \%$ を採用して行うのが精度と簡便さから妥当で あると考える。

\section{5. 建物床面の微振動予測}

建物床面の微振動予測は、基礎 Pit の微振動を入力とする建物の 応答解析によって行う。その際、建物計画時の応答予測では、建物 振動諸元が精度良く確定しているわけではないので、比較的簡便な

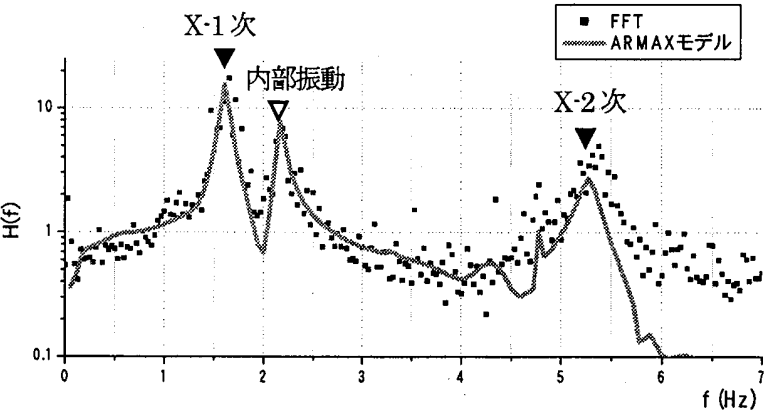

(a) X方向 No.3 $0 \mathrm{sec}-300 \mathrm{sec}$

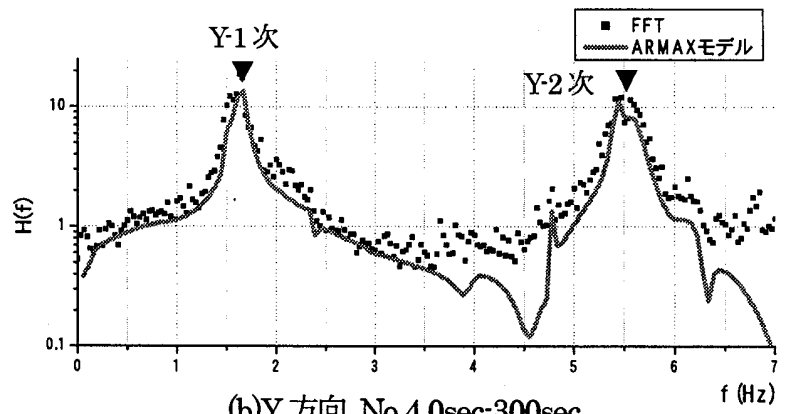

(b)Y 方向 No.4 0sec-300sec

図 8 ARMAX モデルの同定結果

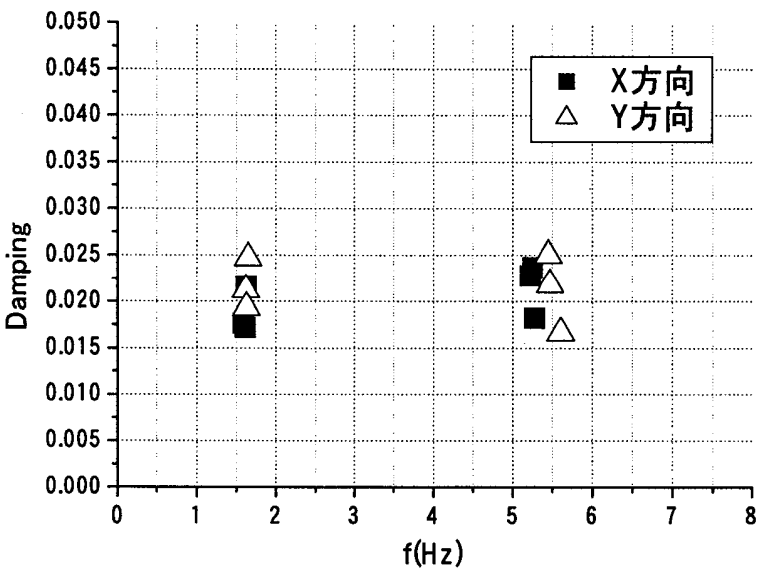

図 9 滅意推定結果

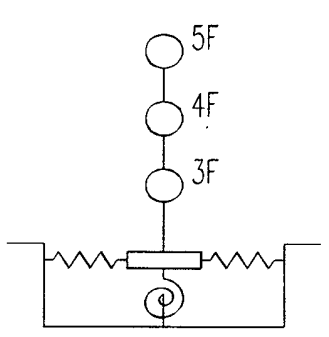

(a)A モデル

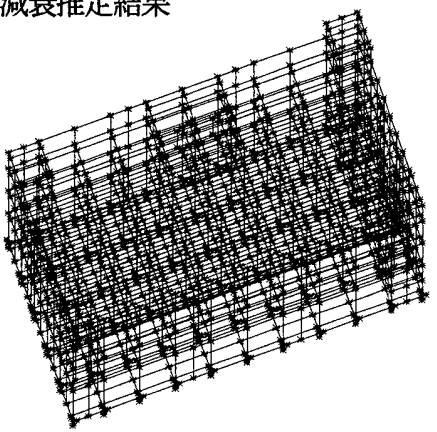

(b)B モデル
図 10 解析モデル概念図

表 3 解析モデル概要

\begin{tabular}{|c|c|c|}
\hline & 解析モデル & 減衰タイプと減衰定数 \\
\hline Aモデル & 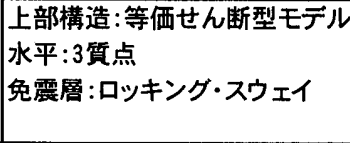 & $\begin{array}{l}\text { 定値減衰 } \\
\text { 上部構造: } 2 \% \\
\text { 兔震層:ロッキング12\% } \\
\text { :スウェイ } 2 \%\end{array}$ \\
\hline B モデル & $\begin{array}{l}\text { 部材レベル立体骨組みモデル } \\
\text { 水平:4質点 }\end{array}$ & $\begin{array}{l}\text { 定値減衰 } \\
\text { 上部構造: } 2 \% \\
\text { 兔震層: } 2 \%\end{array}$ \\
\hline
\end{tabular}


解析モデルを用いることが望まれる。そこで本章では、応答予測手 法で用いる簡易モデル(A モデル)とその予測手法の精度を検証する ための詳細モデル(Bモデル)を用いた時刻歴応答解析を行い、2つの モデルの解析值と実測值を比較検討する。なお、応答解析では、地 盤からの振動のみを考虑し、風や内部振動などの外力は作用しない と仮定している。

応答解析は、応答予測手法で用いる簡易モデル(A モデル)とその予 測精度を検証するための詳細モデル(Bモデル)で行う。

A モデル:上部構造を各階 1 自由度、免震風にスウエイとロッキングを 考慮した多質点モデル

B モデル:部材レベルの立体モデル。水平方向は各階1質点、 3 自由 度 $\left(\mathrm{X}, \mathrm{Y} 、 \mathrm{R}_{\mathrm{Z}}\right)$

部材のモデル化は設計図畫に基づいたが、免震層鈶ダンパーの水 平剛性は微小振動を考慮して 3.7 倍とし、積層ゴムの鈶直剛性は地盤 を考虑し 0.78 倍している。 》減衰は定值減衰とし、上部構造·免震層水 平を $\mathrm{h}=0.02$ とした。入力波として、波形 No.3、No.4の 6D-Pitにおけ る実測波を用いた。図 10 に解析モデル概念図を、表 3 に解析モデル の概要を示す。

表 4 に A モデル・B モデル、実測波から得られる固有周期を示す。 図 11 に各方向の Pitの入力波、 $\mathrm{A}$ モデル・B モデルの 3F と 5F の時刻 歴応答結果と実測波を示す。X·Y 方向の $3 \mathrm{~F}$ と $5 \mathrm{~F}$ の実測波には、水平 方向の最高次固有周期である $33 \mathrm{~Hz}(\mathrm{~A}$ モデル)のローパスフィルターを かけた。図 12 に、 $\mathrm{X} \cdot \mathrm{Y}$ 方向の $\mathrm{Pit} \cdot 1 \mathrm{~F} ・ 3 \mathrm{~F}$ と $5 \mathrm{~F}$ の速度応答スペクトルを 示す。

$\mathrm{A} \cdot \mathrm{B}$ モデルとも加速度時刻歴波形は、加速度の絶対值、1次周期は 比較的実測値と一致している。しかし、高振動数領域では詳細モデル においても振幅がかなりさくなつている。また、速度応答スペク外ルで は、概ねピークを捉えているが、X 方向で 0.46(sec)のピークが両モデ ル共に評価できなかった。このピークは減衰推定の際に述べたようこ 他の測定日では見られず、内部振動によるものと考えられる。モデル 化の違いは、A モデルでは評価することが出来ない高振動数領域を、 Bモデルでは若干であるが捉えることが出来ている点である。

設計時には加速度の絶対值が問題になるので、簡易なモデル化で の解析で十分と考えられる。内部振動が計画時点で特定できる際には、 別途内部振動を評価する必要がある。

\section{6. まとめ}

本研究では計画中の免震建物の微振動レベルを把握することを目 的に、振動源を地盤の微振動のみとし、風力や建物内部の振動は作 用しないという仮定とした上で、敷地地盤の微振動測定デー夕を基 に、免震建物の床応答を予測する手法を提示し、その応答予測手法 の妥当性を評価してきた。得られた結果は以下の通りである。

（1）地盤から基礎への伝達では、井口により示された地震動に位 相差を考虑したときの、自由地表面と基礎の入力動との関係 を表す周波数伝達関数を用いることにより、微振動時の入力 動も比較的良好に予測を行うことが出来た。その際には、基 礎柔性を考慮し、基礎幅を低減することにより実測と良い一 致を示した。

(2) 微振動時の免震建物の減衰は、1次で $1.5 \%$ から $2.5 \%$ にあり、 微振動の応答予測の解析においては、定值減衰 $2 \%$ を設定す
表4 固有周期

\begin{tabular}{|c|c|c|c|c|c|c|}
\hline \multirow{2}{*}{} & \multicolumn{3}{|c|}{ X方向周期 } & \multicolumn{3}{c|}{ Y方向周期 } \\
\cline { 2 - 7 } & 次 & 2次 & 3次 & 1次 & 2次 & 3 次 \\
\hline 実測波 & 0.62 & 0.18 & 0.12 & 0.62 & 0.19 & 0.13 \\
\hline Aモデル & 0.64 & 0.14 & 0.06 & 0.64 & 0.14 & 0.07 \\
\hline Bモデル & 0.64 & 0.16 & 0.06 & 0.63 & 0.16 & 0.10 \\
\hline
\end{tabular}
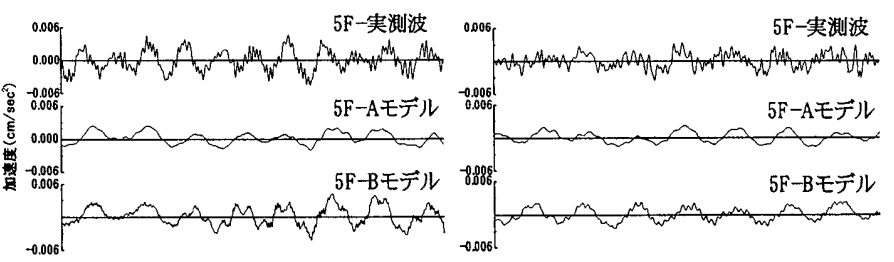

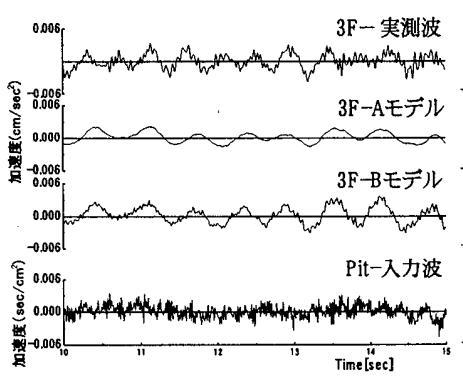

X方向

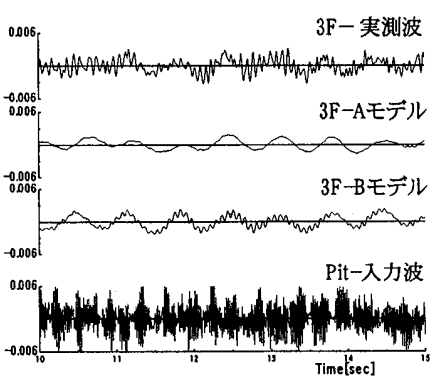

Y方向
図 11 応答解析結果 (時刻歴加速度波形)
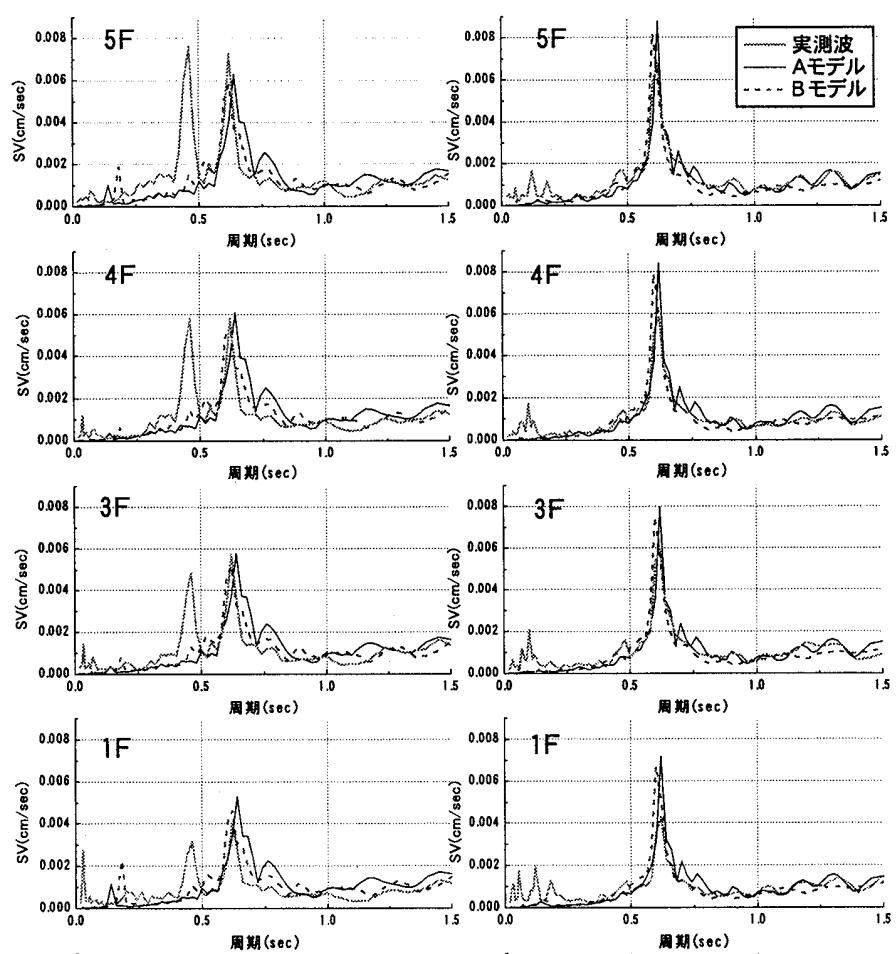

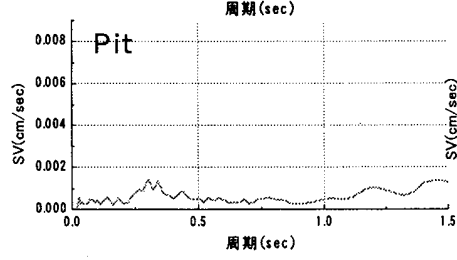

$\mathrm{X}$ 方向

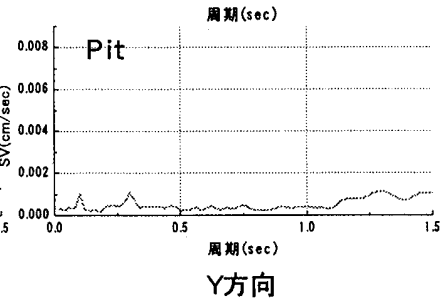

Y方向
図12 応答解析結果 (速度応答スペクトル) 


\section{ることが精度と簡便さから妥当である。}

（3）建物基礎部の微振動波形から建物床面の微振動予測を行う 解析モデルは簡易なロッキング・スウェイモデルで振動レベ ルの概略の把握が十分行えた。

これらの結果をふまえて、免震建物の微振動応答予測の為のフロ 一チャートを図 13 に示す。(1)(2)(3)では、微振動を予測する上で必要 となる基本データの取得、(4)(5)にいて、諸元值から入力損失フィ ル夕を決定し、基礎入力動の算出。6(7)では、簡便なモデルを用い た水平動の応答解析をし、最終的に这建物床面の微振動とする。な お、本報告の評価建物では、微振動時においても剛心と重心が比較 的一致し、据れの影響が少ないとし据れの解析を行わなかったが、 微振動時に剛心と重心が極端に離れる場合には、899)で示すように 別途据れを解析により求める必要がある。

今後の課題としては、本研究では対象建物を 1 物件に絞り考察を してきたため、対象建物を増やし一般性を持たせる必要がある。特 に、入力損失フィルタの影響は大きく、これらの定数設定方法の一 般性が求められる。また、精密機器では水平方向の微振動と同様に 上下方向についても微振動レベルが厳しく設定されているため、上 下方向に対する免震建物の微振動応答予測手法の提案、検証を行つ ていきたい。

\section{参考文献}

1)江利川俊明,吉江慶祐他:免震建物の常時微動振動性状(その 1,2), 日本建築学 会大会学術梗概集 no.40149,no.40150(2000)

2)竹内真次, 深澤尚宏, 吉江慶祐他:免震建物の常時微動振動性状(その 3,4,5), 日 本建築学会大会学術梗概集 no.21279,no.21280(2002)

3)深澤尚宏, 北村春幸他:免震建物の常時微動振動性状(その 6), 日本建築学会大 会学術梗概集 no.21253(2003)

4)井口道雄:地震動の位相差及地盤一構造物の相互作用を考慮した地震応答, 日本地震工学シンポジウム論文集,pp.211-218,1973 年

5)足立修一MATLAB による制御のためのシステム同定,東京電機大学出版局 1996 年

6)斉藤知生:モード解析型多入力多出力 ARX モデルを用いた高層建物のシス テム同定,日本建筑学会構造系論文集,第 508 号,pp47-53,1998 年 6 月 7)田治見宏:建築振動学,コロナ社,1965 年

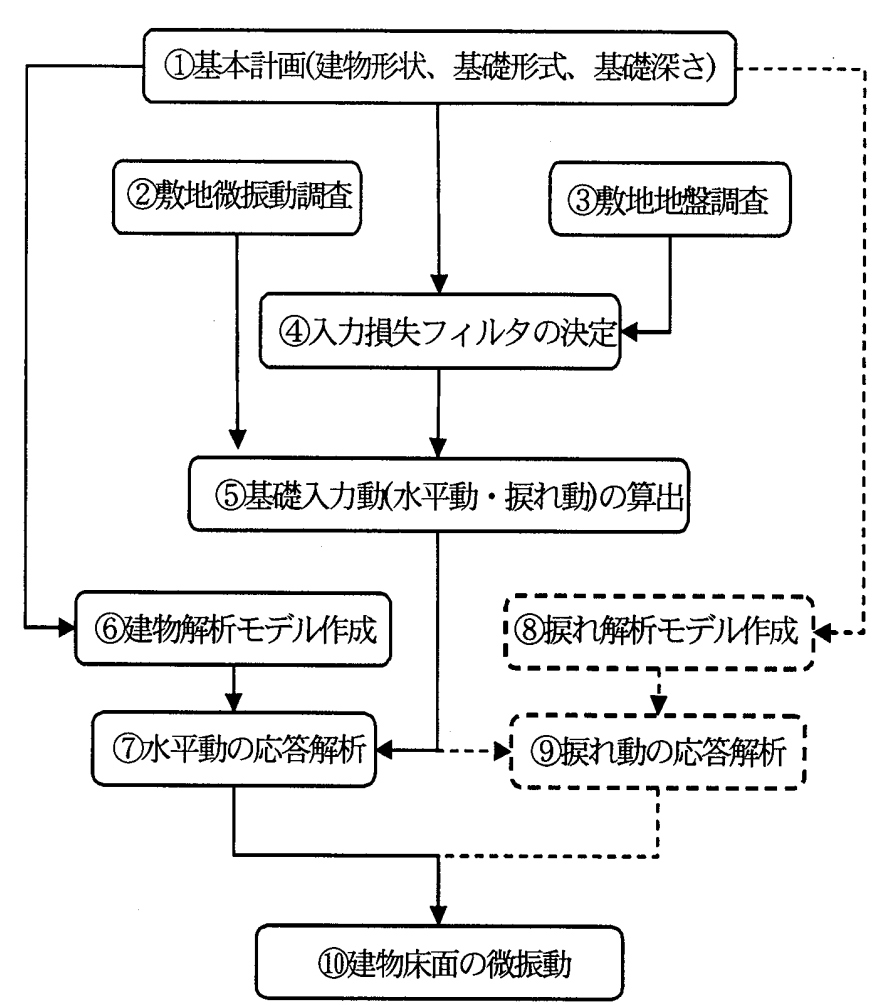

図 13 免震建物の微振動応答予測フローチャート

謝辞

本研究は、DIS 研究会における成果をまとめたものです。貴重なご助言、ご 指導賜りました関係各位に厚く御礼申し上げます。

DIS 研究会

委員長 藤田隆史（東京大学生産技術研究所 教授）

委 員 嶋崎守 (東京大学生産技術研究所)

浅野美次 吉江慶祐 寺田隆一，江利川俊明，鍋沢斤吾 (日建設計) 安田正志, 松田隆司 (特許機器)

北村春幸, 深睪尚宏, 浮田一志, 森清宣貴 (東京理科大学)

減衰推定における同定手法では、電力中央研究所の金澤健司博士に貴重なご 助言を賜りました、厚く御礼申し上げます。

[2003年10月20日原稿受理２004年 2 月23日採用決定］ 